\title{
Bearly Guilty: Understanding Human-Andean Bear Conflict Regarding Crop Losses
}

\author{
Viviana Albarracín ${ }^{1 *}$ and Enzo Aliaga-Rossel ${ }^{2}$ \\ ${ }^{1}$ Ecology and Conservation Postgraduate Program, University Mayor de San Andrés, Campus Universitario, La Paz, Bolivia. \\ ${ }^{2}$ Institute of Ecology, University Mayor de San Andrés, Campus Universitario, La Paz, Bolivia. \\ *albav7@gmail.com
}

\begin{abstract}
Conflicts between wildlife and humans are increasing worldwide, especially in areas where they coexist and share resources. To investigate attitudes and opinions of the human population towards human-Andean bear (Tremarctos ornatus) conflicts in two indigenous Aymara communities, Chuñavi and Lambate, Bolivia, semi-structured interviews were directed to an adult member of families in the communities. Simultaneously, we registered, monitored, and evaluated 70 farm plots to record evidence of Andean bear and other wildlife damage to the maize crops and plants. We found that the locals thought the bear caused the most damage when, in actuality, the most harmful issues identified for maize crops were environmental factors, followed by parrots and birds. Knowledge of the interactions between wild animals and productive systems can contribute to an understanding of Andean bear-human coexistence.
\end{abstract}

Received March 30, 2018

OPEN ठ ACCESS

Accepted December 1, 2018

DOI 10.14237/ebl.9.2.2018.1300

Keywords Jucumari, Human-bear conflict, Coexistence, Crop damage, Tremarctos ornatus

Copyright (C) 2018 by the author(s); licensee Society of Ethnobiology. This is an open-access article distributed under the terms of the Creative Commons Attribution-NonCommercial 4.0 International Public License (https://creativecommons.org/licenses/by-nc/4.0), which permits non-commercial use, distribution, and reproduction in any medium, provided the original author and source are credited.

\section{Introduction}

Conflicts among wildlife and humans are rapidly increasing worldwide, becoming a threat to the survival of several species, especially in areas where wildlife and human populations are living together and share resources (Dickman 2010; Kaczensky et al. 2004). Conflicts occur when wildlife requirements and needs of human populations overlap, causing economic loss and retaliations against wildlife (Goldstein et al. 2006; IUCN 2005; Romero et al. 2006).

Habitat loss, population growth, and agricultural expansion in rural areas increase the frequency of conflict between humans and wildlife (Dickman 2010). Landscape changes and the transformation of natural areas into agricultural land can exacerbate conflicts between humans and wildlife (Kattan et al. 2004). This new resource opportunity attracts the presence of wildlife looking for food near human locations (Dickman 2010; Hawthorne 1987), causing a negative perception. Negative perceptions towards wildlife often are exaggerated and are related to loss of traditional ecological knowledge. For example, elephants (Loxodonta spp.) do not inflict the majority of the damage to subsistence agriculture but are generally identified as the greatest threat to farmers (Parker et al. 2007). In another case, painted dogs (Lycaon pictus) were blamed more than diseases for stock losses, when in reality it is diseases that cause more damage $(23.5 \%$ loss by diseases vs. $1.8 \%$ caused by painted dogs; Rasmussen 1999).

A variety of birds and mammals cause damage to agricultural crops (Romero et al. 2006). Crop destruction and damage impacts local farmers and indigenous groups through losses in food and income, with repercussions for health, nutrition, and education (Lamarque et al. 2009). Therefore, rural or indigenous communities do not always appreciate the presence of wildlife with which they share the landscape (Albarracín 2010; Madden 2004).

The Andean bear (Tremarctos ornatus) is no exception, as habitat loss and growing human population densities have brought bears into conflict with humans throughout their range (Albarracín et al. 2013; Figueroa 2015; Goldstein et al. 2006). The bears are blamed for attacks on livestock, but mainly for 


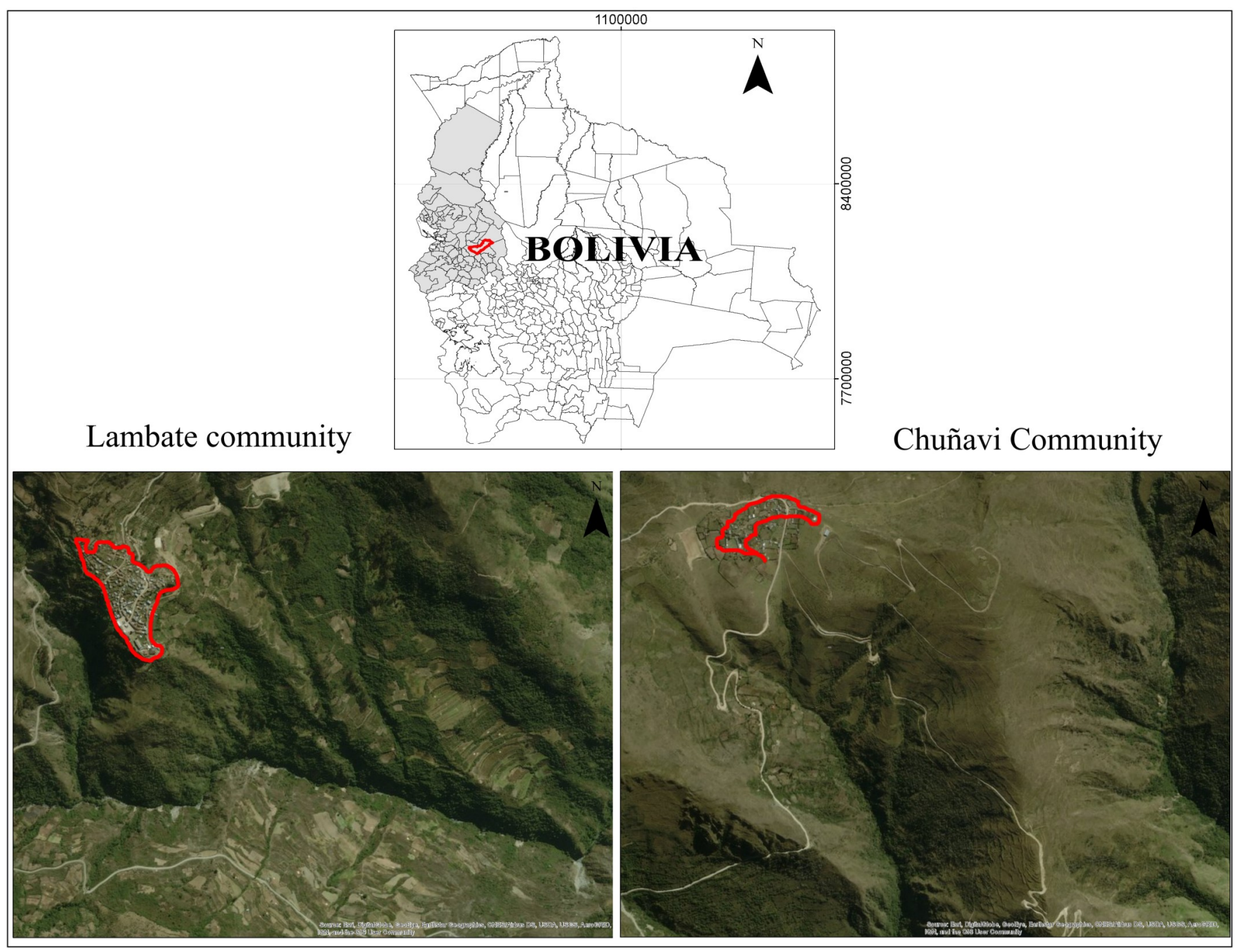

Figure 1 Study site: The red outline areas show the Lambate and Chunavi communities, and both cultivated and forest patches within these communities. South Yungas Province, La Paz Department, Bolivia (Google Earth images were used to produce this figure).

damage to several crops such as corn and cane (Goldstein et al. 2006; Morales 2003). This conflict for resources increases the negative perceptions of and prejudices against bears, which may lead to hunting intended as retaliation for crop damage and to reduce future damage. This deliberate killing of bears increases the risk of extirpation of that species (Albarracín 2010; Figueroa 2015; Goldstein et al. 2006; Torres 2008).

In an analysis of the human-bear conflict related to cattle attacks, Goldstein et al. (2006) indicated that the Andean bear is generally identified as responsible for the majority of cattle deaths. However, they found that locals often overestimate the real number of cattle losses caused by the bear. Albarracín (2010) also studied local indigenous perception, which indicated that Andean bears are believed to be the main causes of cattle losses and crop destruction.

In Bolivia few studies have addressed the conflict from the locals' point of view, although these studies have identified wildlife species as responsible for damage to crops or impacts on the local economy (Morales 2003; Perez and Pacheco 2006). The objectives of our study were to examine the perceptions of locals about the Andean bears, identify the real cause of damage to corn crops, and estimate agricultural losses caused directly by the Andean bear. We also attempted to determine if the distance of the crops to wooded areas has a relation to the damage caused by the Andean bear or other wildlife. We 
hypothesize that crops at shorter distances from the forest are more vulnerable to damage than crops farther from the forest. This study contributes to Andean bear conservation and crop management strategies by understanding the local perception of nature in order to facilitate human-bear coexistence, hopefully advancing conservation of Andean bear populations in the region.

\section{Methods}

Study Location

The study was conducted in two indigenous communities of Bolivia in Lambate canton, South Yungas Province, La Paz Department (16 $30^{\circ}$ $16^{\circ} 40^{\prime} \mathrm{S}$ and $67^{\circ} 30^{\prime}-67^{\circ} 45^{\circ} \mathrm{W}$ ) with an altitude range between $2600 \mathrm{~m}$ and $3400 \mathrm{~m}$. Located in the eastern Cordillera of the Andes, Lambate has deep valleys and is transitional between inter-Andean dry forests and Yungas (Ibisch and Merida 2003). Weather conditions vary according to altitude, but generally are semihumid to humid (Ibisch and Merida 2003). Within a generally temperate climate (annual average 7 to $20^{\circ} \mathrm{C}$ ), between June and September sporadic southern cold fronts known as surazos cause temperatures to fall. The altitude-related changes in vegetation include cloud forests ranging from $800 \mathrm{~m}$ to $3500 \mathrm{~m}$, as well as high altitude grasslands. Much of the study area features steep hillsides (Figure 1). This habitat represents an area of high biodiversity with a number of wildlife species including parrots (Aratinga spp.), several native dove species, Andean bear, skunks (Conepatus chinga rex), and rodents (Albarracín 2010; Yañez et al. 1995).

Native vegetation in several areas has been replaced by subsistence agriculture of broad beans, potatoes, and corn. Corn is a main staple food and is also used for feeding livestock, as well as for sale. Some local people also have sheep, horses, or cattle; however, it is not an intensive activity (Albarracín 2010; Yañez et al. 1995). It is estimated that almost three-quarters of rural inhabitants of Bolivia are poor (Oviedo 2014).

We selected two of the main Aymara indigenous communities in the area, Lambate with 44 families and Chuñavi with 33 families. These were selected because they had previously reported killing Andean bears due to crop losses (Albarracín 2010). Chuñavi is more economically reliant on mining activity, and the forest is disturbed in lower areas of the territory.
Other communities in the area did not report bear presence in their territories.

Data Collection

From February to April 2011, we lived in both communities to conduct the interviews and fieldwork described here. Prior to starting the interviews, we obtained the necessary permits and established informed consent with the communities and informants. Fieldwork began with a workshop with the indigenous people as a general introduction to the project. To be sure we gained the trust of the interviewees, we highlighted that we were not affiliated with any authorities. To increase the reliability of the responses, the interviewers clearly indicated that the respondents' names would be kept confidential.

Attitudes and Opinions about Crop Loss. To investigate attitudes and opinions of the local population regarding conflicts, and to identify possible crop damage and loss caused by wildlife or other factors, especially the Andean bear, two researchers carried out semi-structured interviews. Using the list of all the families in the communities provided by the authorities, the researchers randomly selected families from each community and interviewed one adult member of each family. Refusal rate to participate was $14 \%(\mathrm{n}=11)$ of the total families in both towns. The age of respondents was between 30 and 60 years $($ mean $=45)$. Younger adults tend to migrate to the nearby city of La Paz. With the exception of mining, all families interviewed had the same economic status.

To avoid interrupting daily activities (and following Albarracín 2010), households were visited between 07:30 and 09:30 or from 18:30 to 21:00. The interview usually lasted between 15 and 20 minutes. Visits and interviews were carried out with a local assistant, who translated Aymara if necessary, although most of the respondents preferred Spanish for communication.

Interview questions included general information such as occupation, type of agricultural production, if production was for commercial or subsistence purposes, as well as questions about crop losses and their perception, and participants were asked what type of measures were taken to mitigate crop loss. Then we asked specific questions about the Andean bear, including whether they chase or kill bears, and their specific perception about the species in terms of their density and the effects on crops. To avoid 
influence and bias, we allowed interviewees to finish their answers and explain any issue they considered important, sometimes allowing the participation of their partners. In some instances women refused to participate and on several occasions the entire family was present during the interviews.

For this study, we focused on corn losses, because while previous studies also mentioned damage to potatoes, they did not report that locals assigned responsibility to Andean bears for potato crop damage (Albarracín 2010).

Crop Damage Assessment. To record evidence of wildlife responsible for damage to corn crops during March to May, we evaluated 70 farm plots within the two study areas ( $\mathrm{n}=55$ in Lambate and $\mathrm{n}=15$ in Chuñavi). Some owners were reluctant to authorize our entrance to and evaluation of their crops, particularly in Chuñavi. This reluctance was the reason for the difference in the number of crop plots evaluated between the two sites. Average plot sizes were less than $3500 \mathrm{~m}^{2}$.

Every day, in each plot, we randomly ran linear transects (between 06:00 to 09:00 h) in search of wildlife signs such as feces, tracks, hair, or direct observations, supported by field guides to identify the possible damage caused by mammals (Tarifa et al. 2001; Torres 2008). To track the impact of birds on corn crops, we continuously monitored the area to register species present in the field and find clear signs of bird foraging on the cobs.

We examined all plants affected in the plot to determine the characteristics of crop damage. During each survey, plants and cobs damaged by wildlife were counted and subtracted from the total. The damage due to environmental factors such as drought, sun, and frost was also registered.
We tested the hypothesis that crops at shorter distances from the forest are more vulnerable to damage than crops farther from the forest. We determined crop plot location using a GPS. Then, we calculated the distance of each corn field to the village and to the nearest forest with a laser rangefinder. Crop areas within a 4-7 $\mathrm{km}$ radius of the community center, which is further from the forest, are where fauna are hunted and crops protected (Aliaga-Rossel 2011). Crops near the forest were recorded as areas adjacent to and up to $4 \mathrm{~km}$ from the native forest.

Analyses

For the analysis of the crop assessment, we used Pearson's Chi-squared test with Yates' continuity correction (Yates 1984).

\section{Results}

In total, 55 interviews were performed: 25 families in Chuñavi ( $76 \%$ of the total families of the community) and 30 families in Lambate (68\% of the total Lambate community).

Most families are dedicated exclusively to agriculture $(46 \%)$, while others combine this activity with mining or other business. A few families also have cattle, sheep, or pigs. Approximately $20 \%$ of the families rely exclusively on mining for income and do not have crops. The majority of corn production was only for self-consumption (67\%), and only $13 \%$ of the families might sell the excess production. We found that the most important crops were corn, followed by potatoes and other tubers. Corn was also used to feed livestock.

All respondents in both communities agreed and recognized that there have been environmental changes in the area, including changes in rainfall regimes, increased temperature, and strong solar

Table 1 Perception of the communities of Lambate and Chuñavi, La Paz, in relation to causes of crop damage or losses.

\begin{tabular}{lllllll}
\hline & \multicolumn{2}{c}{ Lambate } & \multicolumn{2}{c}{ Chuñavi } & \multicolumn{2}{c}{ Total } \\
\hline Causes to loss & $\mathbf{n}$ & $\%$ & $\mathbf{n}$ & $\%$ & $\mathbf{n}$ & $\%$ \\
Andean Bear & 10 & 30 & 7 & 24 & 17 & 31 \\
Birds (including parrots) & 3 & 10 & 4 & 16 & 7 & 13 \\
Other/Wildlife not ID & 1 & 3 & 1 & 4 & 2 & 4 \\
Environment problems & 6 & 20 & 5 & 20 & 11 & 20 \\
No problems & 4 & 13 & 3 & 12 & 7 & 13 \\
No crops & 6 & 20 & 5 & 20 & 11 & 20 \\
\hline
\end{tabular}


60

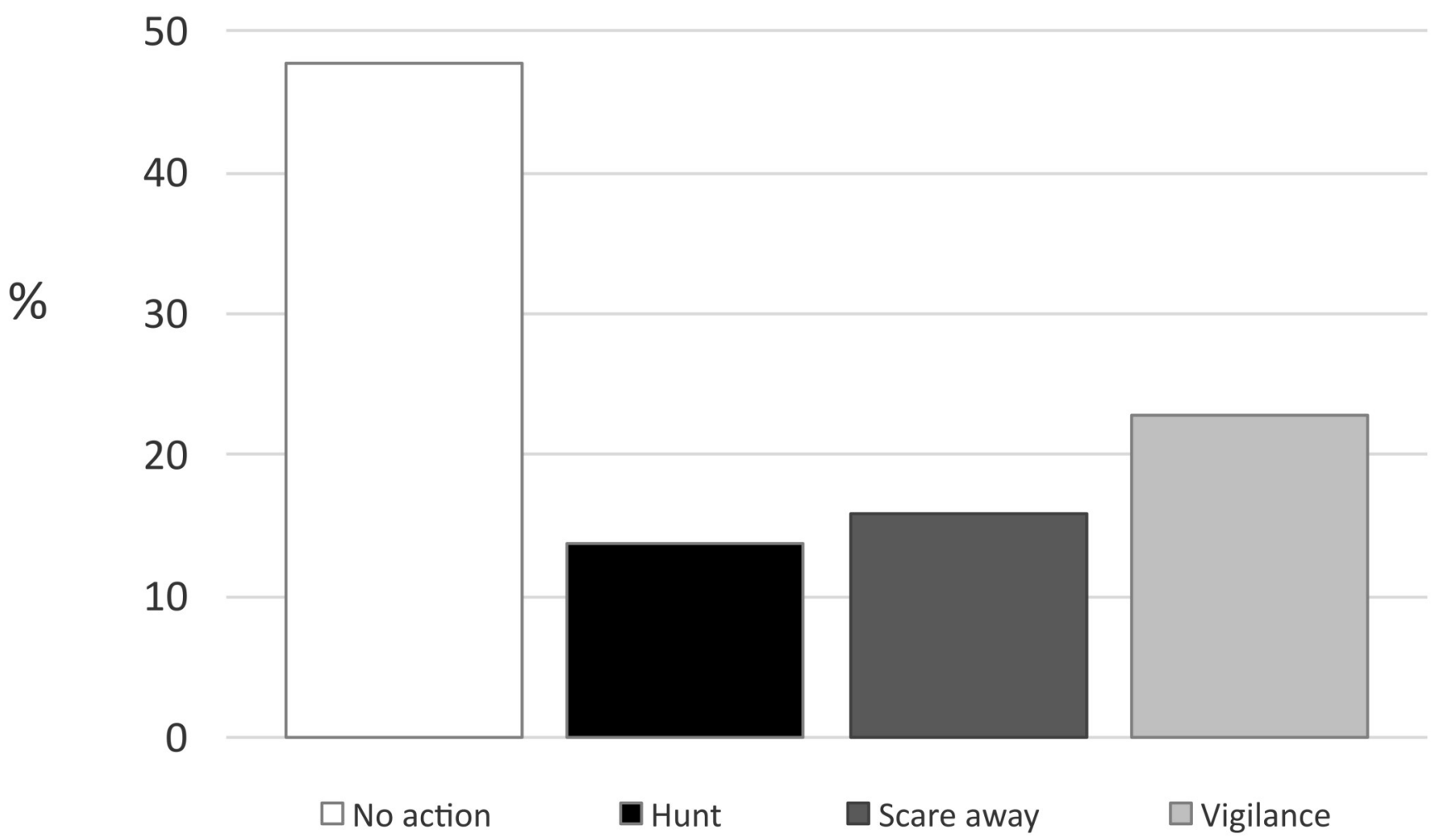

Figure 2 Actions taken against Andean bear presence in crops: no action, hunting them, scare them away, and constant vigilance.

radiation. Also, all elders mentioned the absence or reductions in wildlife sightings. Although the majority of those interviewed ignored the causes of all of these changes, they indicated general concern about a perception of alterations in the climate.

The communities had different perceptions of crop damage and the causes of crop losses (Table 1). Though respondents attributed corn crop losses to the Andean bear (31\% of respondents, $n=17$ ), birds, including parrots, were also blamed for crop losses $(13 \%)$ (Table 1). In total, $20 \%(\mathrm{n}=11)$ indicated that the main cause of crop losses is climate related, placing responsibility on weather events such as droughts and cold fronts, while 13\% $(\mathrm{n}=7)$ did not identify problems with crop losses. Eleven of those interviewed are miners and do not have crops, and therefore do not have any conflict with bears. Thus, their data without losses were excluded.
When asked about their perceptions of corn crop losses due to Andean bears (Figure 2), 48\% ( $\mathrm{n}=21)$ indicated that they do not take any further action, $16 \%$ retaliated by attempting to hunt bears to control or avoid the crop loss, $16 \%(\mathrm{n}=7)$ scare bears away using fireworks, although they are not always satisfied with the efficiency of this method, and ten families frequently control and watch their crops. The vast majority of the locals $(92 \%, n=47)$ indicate they do not kill bears; however, they are willing to kill them if necessary. Eight percent $(n=5)$ have already killed an Andean bear. The majority $(87 \%, \mathrm{n}=48)$ did not perceive birds as a strong cause of crop losses, and few mentioned insects or other wildlife such as skunks (Conepatus chinga).

Andean Bear Conservation. Only 16\% ( $\mathrm{n}=9)$ of the respondents agreed that the bear should be conserved, 
$45 \%(\mathrm{n}=25)$ agreed that there should be bear population control, and 16\% $(\mathrm{n}=9)$ emphasized that bears should be exterminated. From the respondents against bear conservation, they highlight that laws are biased towards wildlife and conservation, or that conservation laws were not useful to them, especially in economic terms.

Corn Crop Damage Assessment. In the 70 maize plots we studied, we registered crop plots that had been damaged and what caused the damage. We observed two main causes of crop damage to maize crops. From the 55 registered plots in Lambate, 40\% ( $\mathrm{n}=$ 22) showed crop damage caused by wildlife; $44 \%$ ( $n=$ 24) of losses were caused by environmental factors such as rain, excessive sun (called as K'asawi in Aymara) and cold fronts; in the plots, climate factors caused $23 \%$ of losses in Lambate and 18\% for Chuñavi. Sixteen percent of the plots did not present any damage or attacks to the crops. In the 15 surveyed plots in Chuñavi, 27\% $(\mathrm{n}=4)$ showed some damage by wildlife, and 40\% ( $\mathrm{n}=6)$ presented damage caused by environmental conditions. We could not determine the cause of damage to one field. The remaining crops are constantly watched and monitored by their owners and did not have any important damage. We registered higher climaterelated damage compared to damage caused by wildlife. We found plants without fruits, dry or rotten. Some climate-related records of damage are linked to the direct sunlight and not to the slope or soil texture.

Main Causes of Crop Loss Due to Wildlife. From the 22 plots damaged by wildlife in Lambate, $59 \%(\mathrm{n}=13)$ of the damage was caused by birds, primarily parrots (Aratinga sp.) and ch'iguancu (Turdus chiguancu), and $41 \%(\mathrm{n}=9)$ was caused by the Andean skunk (Conepatus chinga rex). In Chunhavi, the majority of the damage was caused by birds (i.e., parrots) and skunks.

Parrots/parakeets were the species that caused most damage to crops. Parrots in pairs and/or groups of up to 100 individuals were observed, which fly to different crop areas throughout the day. The parrots cling with their feet to the stem of the plant and open the cobs from the apex. After eating, their feces could be seen on the leaves and the plant. Skunks caused losses of $3 \%$ of the total crop in the community in Lambate and 5\% in Chuñavi. They dig at the base of corn plants looking for larvae that feed on the roots of plants, consequently killing the plant.
During the survey and study period, we did not observe nor receive reports about maize crop damage caused by Andean bears. As we predicted, plots with the greatest damage were located near the forest $(\chi$ square $=6.2, \mathrm{df}=1, p$-value $=0.012, p<0.05)$. Plots that were closer to the town had minor damage and were characterized by being very close to dirt trails where people often walked and are present.

\section{Discussion}

The interviews highlighted a general concern and perception about climate change and decreasing wildlife abundance. Some of the interviewees also perceived a connection between crop losses and climate change; however, the majority still blame wildlife for their crop damage and losses. A variety of wildlife species around the world have been blamed for losses (e.g., Aliaga- Rossel 2011; Hill 2000; Madden 2004; Morales 2003; Pérez-Torres 2001; Waladgi and Tchmba 2003). This negative perception presents a major challenge for conservation efforts, as local people place the majority of blame for crop losses on wildlife. Wildlife, however, are likely not the primary cause of crop loss, and this misplacing of blame may prevent people from focusing on more significant or genuine threats.

During this study, there was no evidence or confirmed reports of Andean bear in the area, nor any losses caused by the species. Contrary to local perceptions, Andean bears were not the main crop threat and did not represent a major problem for the crops during our study period. Nevertheless, the negative perception remains. Many people support bear conservation (45\%), but only if bear populations are managed, so as not to have more damage to their corn crops.

In this study, locals considered Andean bears as agricultural pests and blamed them for crop and livestock losses. Locals may also have exaggerated blame towards the Andean bear for crop damage caused by climate and other wildlife, such as parakeets. Between 1993 and 1994 at least 13\% of Lambate and Chuñavi residents claimed to have seen the bear amidst their crops eating corn (Yañez et al. 1995). In the same area, locals reported several corn losses caused by the bear; however Albarracín (2010) observed an Andean bear only once during the daytime, walking away from the remains of consumed corn cobs. Hairs and traces of this species were found 
in four farm plots. Albarracín (2010) found that locals in the study area paradoxically also considered Andean bears to be a deity and therefore were reluctant to harm them. This highlights the importance to promote traditional ecological knowledge, as these cultural beliefs could be used as a conservation tool.

Only a small percentage of people proposed killing the bear as the best solution. The self-reported Andean bear hunters indicated that they were the reason bears no longer visit maize crops in the higher areas. We could not verify this claim since other people feared retaliation from hunters. Also, hunters were substantially less tolerant than non-hunters (Knopff et al. 2016), and indicated they will do it again if needed, and if they have problems with bears, they cannot count with any authority to help them, and prefer to "eliminate the problem". This was also discussed by Dickman (2010), who indicated that the response to conflict often appears disproportionate and even a small level of wildlife damage can still elicit harsh responses.

Despite the use of scarecrows or flagging actions, parakeets were the main cause of crop damage. Perez and Pacheco (2006) found that birds and monkeys alone could destroy up to $77 \%$ of a potential corn crop in Cotapata National Park in Bolivia.

Local people did not show such a negative reaction towards other wildlife. They rarely mentioned skunks as a source of crop damage, although we observed them digging up roots in search of larvae and insects, especially the locally called lak'ato (Scarabidae). Skunks also ate maize by pulling the plant top to reach the cob. We also observed sheep feeding on remote corn crops neglected by their owners. Although free-ranging domestic animals contribute to crop losses, they are less likely to be blamed than bears or other carnivores, which may increase negative perceptions of these species, similarly observed for the sun bear (Helarctos malayanus; Guharajan et al. 2017).

We identified people who are not completely in favor of Andean bear conservation, and as mentioned previously, they perceive that laws are biased towards wildlife and conservation, or that conservation laws were not useful to them. This negative attitude could increase, turning other members against local authorities (Madden 2004). This low human tolerance for carnivores is mainly caused by fear or a negative prejudice (Albarracín, 2010; Servheenet al. 1999).
More than four to five bears were killed in the area during a previous study (Albarracín, 2010), but not during our study. A possible explanation could be a better and more positive bear perception due to environmental education campaigns performed during 2011. There is also the possibility that because of past killings, there are fewer bears in the area. We observed some signs of bears in the nearby forest, which precludes the possibility that bears were totally absent in the area.

Mining activity has increased during this time and several mining cooperatives are functioning in the area; therefore, the residents of the studied communities prefer to engage in mining rather than agriculture. As the cooperative mining camps increase, dynamite explosions are more frequent. This noise may terrify the Andean bear in the area, perhaps displacing bears and explaining the reduced observations in the last few years. Despite the reduced number of sightings and damage to crops, the perception of the people towards the Andean bear remains negative. The substantial overestimation of risk associated with carnivores, including bears, could be the result of a cognitive illusion, which occurs when rare events are so memorable and easily recalled that individuals overestimate their frequency (Knopff et al. 2016).

As we predicted, plots located nearer to the forest were more often visited by wildlife and had higher damage (Figueroa 2015; Kattan et al. 2014). As the distance from the village center increases, farm plots are not visited as often. Locals admit that they did not usually look after their crops when they are located near the forest. Further, they are not willing to take further actions. Damage varies from crop to crop and locality. Net losses were almost $40 \%$ when closest to the forest and gradually reduced over a distance of about 5-6 km, especially when closer to human settlements. Bears naturally avoid humans but can become habituated to areas occupied by humans when they provide an easy source of food (Belant et al. 2011; Conover 2008), thereby increasing conflicts and negative perceptions of the species. Similar outcomes were registered in communities near the Natural Area of Integrated Management Apolobamba (Morales 2003), where locals indicated that most of the damage by wildlife is usually in crops near the forest edge. Andean bears were one of the main culprits of wildlife-related crop damage. 
Since the blame for damage is being incorrectly attributed, our work suggests that there is a greater need for environmental education. Education and outreach programs could help teach locals that the Andean bear is not responsible for their crop losses, while also increasing knowledge of the ecological role bears play and the importance of healthy forests. Environmental education programs can be a successful conservation strategy (Smith 2015; Van der Ploeget al. 2011). In Europe, Kaczensky et al. (2004) found that positive perceptions of black bears and wolves were related to higher levels of education and more knowledge about those species; therefore, by acquiring accurate information, human-Andean bear conflicts can be reduced (Albarracín et al. 2013; Atwood and Breck 2012; Conover 2008; Dickman 2010; Figueroa 2015), effectively promoting the coexistence humans and bears. Locals could also be encouraged to become advocates for conservation.

Finally, we conclude that climate was the primary reason for damage to maize and other crops, followed by parakeets and skunks. Although there is some evidence that Andean bears do attack crops (Figueroa 2015; Goldstein et al. 2006; Morales 2003), they are blamed for substantially more losses than they actually cause. It is much easier to blame bears than to admit that a farmer does not look after their crops. During our study period, we did not find evidence that the Andean bear had caused damage to crops. When we visited the area two years later, locals were still attributing crop losses to bears.

Knowledge of the interactions between wild animals and production systems through studies such as this can contribute to the generation of alternatives for better crop management and wildlife conflicts. Human-carnivore coexistence is possible even with human population presence. This requires long-term education campaigns and proactive prevention of conflict.

\section{Acknowledgments}

Thanks to the popular Education Center Qhana in Chuñavi, for support in logistics, and to the Aymara indigenous communities Lambate and Chuñavi for allowing us to work with them. Thanks to Sheena Barrenechea who assisted during all the stages of the fieldwork. Rob Wallace, Sarah Dalle, Lana M. Ciarniello, Mac Marston, Andrew Gillreath-Brown, and Nicolas Molina gave important suggestions for the manuscript.

\section{Declarations}

Permissions: None declared.

Sources of funding: This work was supported by PUMA foundation, Conservation International-Bolivia, and the Estás Vivo foundation, which provided the grant that allowed this research through the Werner Hanagarth Scholarship.

Conflicts of Interest: None declared.

\section{References Cited}

Alexiades, M. 1999. Ethnobotany of the Ese Eja: Plants, Health, and Change in an Amazonian Society. Unpublished Doctoral Dissertation, Department of Biology, The City University of New York, New York.

Albarracín, V. 2010. Percepción Actual de los Pobladores Locales del Cantón Lambate sobre el Jucumari (Tremarctos ornatus) La Paz - Bolivia. Unpublished Bachelor's Thesis, Universidad Tecnológica Boliviana, La Paz, Bolivia.

Albarracín, V., S. Paisley, E. Aliaga-Rossel, and X. Vélez Liendo. 2013. State of the Andean Bear (Tremarctos ornatus) in Bolivia. In Molecular Population Genetics, Evolutionary Biology and Biological Conservation of Neotropical Carnivores, edited by M. Ruiz-Garcia and J. M. Shostell, pp. 507-602. Nova Publishers, New York.

Aliaga-Rossel, E. 2011. The Cascading Effect of Mammal Species Defaunation on Seed and Seedling Survivorship as a Result of Hunting. Unpublished Doctoral Dissertation, Ecology Evolution and Conservation Biology Program, University of Hawaii at Manoa, HI.

Atwood, T. C., and S. W. Breck. 2012. Carnivores, Conflict, and Conservation: Defining the Landscape of Conflict. USDA National Wildlife Research Center: Staff Publications, Paper 1620. Available at: h t t p: / / digitalcommons.unl.edu / icwdm_usdanwrc/1620. Accessed on September 1, 2018.

Belant, J. L., S. L. Simek, and C. Ben West. 2011. Managing Human-Black Bear Conflicts. Humanwildlife Conflicts 1:1-77. Available at: http:// www.humanwildlifeconflicts.msstate.edu/docs/ Black\%20bear\%20Final\%2012-7-11.pdf. Accessed on June 1, 2018. 
Conover, M. 2008. Editor's Introduction: Why Are So Many People Attacked by Predators? Human-Wildlife Conflicts 2:139-140.

Dickman, A. J. 2010. Complexities of Conflict: The Importance of Considering Social Factors for Effectively Resolving Human-Wildlife Conflict. Animal Conservation 13:458-466. DOI:10.1111/ j.1469-1795.2010.00368.x.

Figueroa, J. 2015. Human-Andean Bear Tremarctos ornatus Interactions in Peru: Crop Consumption and Cattle Depredation. Therya 6:251-278. DOI:10.12933/therya-15-251.

Goldstein, I., S. Paisley, R. Wallace, J. Jorgenson, F. Cuesta, and A. Castellanos. 2006. Andean Bear Livestock Conflicts: A Review. Ursus 17:8-15. DOI:10.2192/1537-6176(2006)17[8:abcar]2.0.co;2.

Guharajan, R., N. K. Abram, M. A. Magguna, B. Goossens, S. T. Wong, S. K. S. S. Nathan, and D. L. Garshelis. 2017. Does the Vulnerable Sun Bear Helarctos malayanus Damage Crops and Threaten People in Oil Palm Plantations? Oryx 1-9. DOI:10.1017/S0030605317001089.

Hawthorne, W. D. 1987. Daños Provocados por Animales Silvestres y Técnicas de Control [Damage Caused by Wildlife and Control Techniques]. In Manual de Técnicas de Gestión de Vida Silvestre, edited by S. D. Schemnitz, pp. 431-462. The Wildlife Society, Bethesda, MD.

Hill, C. 2000. Conflict of Interest Between People and Baboons: Crop Raiding in Uganda. International Journal of Primatology 21:299-315. DOI:10.1023/ A:1005481605637.

Ibisch, P. L., and G. Mérida, eds. 2003. Biodiversidad: La Riqueza de Bolivia. Estado de Conocimiento y Conservación. Ministerio de Desarrollo Sostenible, Editorial FAN, Santa Cruz, Bolivia.

International Union for the Conservation of Nature (IUCN). 2005. Benefits Beyond Boundaries: Proceedings of the Vth IUCN World Parks Congress. Durban, South Africa, September 1-17, 2003. Gland, Switzerland and Cambridge, United Kingdom.

Kaczensky, P., M. Blazic, and H. Gossow. 2004. Public Attitudes Towards Brown Bears (Ursus acrtos) in Slovenia. Biological Conservation 118:661-674. DOI:10.1016/j.biocon.2003.10.015.

Kattan, G., L. Hernández, I. Goldstein, V. Rojas, O. Murillo, C. Gómez, H. Restrepo, and F. Cuesta.
2004. Range Fragmentation in the Spectacled Bear Tremarctos ornatus in the Northern Andes. Oryx 38:155-163. DOI:10.1017/S0030605304000298.

Knopff, A., K. H. Knopff, and C. Clair. 2016. Tolerance for Cougars Diminished by High Perception of Risk. Ecology and Society 21:33. DOI:10.5751/ES-0893 3-210433.

Lamarque, F., J. Anderson, R. Fergusson, M. Lagrange, Y. Osei-Owusu, and L. Bakker. 2009. Human-Wildlife Conflicto in Africa. Causes, Consequences and Management Strategies. Forestry paper 157. Food and Agriculture Organization of the United Nations, FAO, Rome, Italy.

Madden, F. 2004. Creating Coexistence between Humans and Wildlife: Global Perspectives on Local Efforts to Address Human-Wildlife Conflict. Human Dimensions of Wildlife 9:247-257. DOI:10.1080/10871200490505675.

Morales, A. 2003. Evaluación de Daños Causados por Vertebrados Silvestres en Maizales de Pajan, K'apna y Wayrapata. Unpublished Bachelor's Thesis, Biology Department Universidad Mayor de San Andrés, La Paz, Bolivia.

Oviedo, V. 2014. Rural Poverty, Vulnerability and Food Insecurity. The Case of Bolivia. Potsdam Economic Papers: 3. Potsdam University Press, Potsdam, Germany.

Parker, G. E., F. V. Osborn, R. E. Hoare, and L. S. Niskanen. 2007. Human-Elephant Conflict Mitigation: A Training Course for CommunityBased Approaches in Africa. Participant's Manual. Elephant Pepper Development Trust, Livingstone, Zambia and IUCN/SSC AfESG, Nairobi, Kenya.

Perez, E., and L. F. Pacheco. 2006. Damage by Large Mammals to Subsistence Crops within a Protected Area in a Montane Forest of Bolivia. Crop Protection 25:933-939. DOI:10.1016/j.cropro.2005.12.005.

Pérez-Torres, J. 2001. Guia para la Conservación del Oso Andino u Oso de Anteojos (Tremarctos ornatus). Convenio Andrés Bello, Colombia.

Rasmussen, G. S. A. 1999. Livestock Predation by the Painted Hunting Dog Lycaon pictus in a Cattle Ranching Region of Zimbabwe: A Case Study. Biological Conservation 88:133-139. DOI:10.1016/ S0006-3207(98)00006-8.

Romero, K., E. Naranjo, H. Morales, and R. Nigh. 2006. Daños Ocasionados por Vertebrados 
Silvestres al Cultivo de Maíz en la Selva Lacandona, Chiapas, México. Interciencia 31:276-283.

Servheen, C., S. Herrero, and B. Peyton. 1999. Bears. Status Survey and Conservation Action Plan. IUCN/SSC Bear and Polar Bear Specialist Groups, Gland Switzerland and Cambridge, United Kingdom.

Smith, C. A. 2015. Large Carnivore Conservation: Integrating Science and Policy in the North American West. International Journal of Environmental Studies 72:897-899. DOI:10.1080/00207233.2015.1 073476.

Tarifa, T., E. Aliaga- Rossel, D. Hagaman, and B. Ríos. 2001. Mammals of the Madidi National Park. Conservation International - Bolivia. Available at: https://www.academia.edu/35513529/2001 Guia_mamiferos_Madidi_BoliviaPROTEGIDA.pd f. Accessed on November 1, 2017.

Torres, D. A. 2008. Caracterización de Conflictos Socio-Espaciales entre la Ganaderia y los grandes Mamiferos Carnivoros en el Sector Cuenca del Rio Nuestra Senora. Parque Nacional Sierra Nevada, Venezuela. Trabajo especial de Grado, Escuela de Geografia, Facultad de Ciencias Forestales y Ambientales, Universidad de los Andes, Mérida, Venezuela.
Van der Ploeg, J., M. Cauilan-Cureg, M. van Weerd, and W. T. de Groot. 2011. Assessing the Effectiveness of Environmental Education: Mobilizing Public Support for Philippine Crocodile Conservation. Conservation Letters 4:313-323. DOI:10.1111/j.1755-263X.2011.00181.x.

Waladji, R. B., and M. N. Tchamba. 2003. Conflict Between People and Protected Areas within the Benoue Wildlife Conservation Area, North Cameroon. Oryx 37:72-79. DOI:10.1017/ S0030605303000140.

Yañez, M., E. Luna, R. Miserendino, and L. Maffei. 1995. El Oso Jukumari en la Región de Lambate. [The Andean Bear in Lambate Region]. ICAP. Instituto Científico "Alax Pacha" Secretaria Ejecutiva PL 480, Bolivia.

Yates, F. 1984. Tests of Significance for 2 X 2 Contingency Tables. Journal of the Royal Statistical Society. Series A (General) 147:426-463. DOI:10.2307/2981577. 